\title{
Influence of the Consciousness Energy Healing Treatment on the Physicochemical, Spectral, Thermal and Behavioral Properties of Sodium Selenate
}

\author{
Mahendra Kumar Trivedi ${ }^{1}$, Alice Branton ${ }^{1}$, Dahryn Trivedi ${ }^{1}$, Gopal Nayak ${ }^{1}$, \\ Barry Dean Wellborn ${ }^{1}$, Deborah Lea Smith ${ }^{1}$, Dezi Ann Koster ${ }^{1}$, Elizabeth Patric ${ }^{1}$, Jagdish Singh ${ }^{1}$, \\ Kathleen Starr Vagt ${ }^{1}$, Krista Joanne Callas ${ }^{1}$, Parthasarathi Panda ${ }^{2}$, Kalyan Kumar Sethi ${ }^{2}$, \\ Snehasis Jana ${ }^{2, *}$ \\ ${ }^{1}$ Trivedi Global, Inc., Nevada, USA \\ ${ }^{2}$ Trivedi Science Research Laboratory Pvt. Ltd., Bhopal, India
}

Email address:

publication@trivedieffect.com (S. Jana)

${ }^{*}$ Corresponding author

\section{To cite this article:}

Mahendra Kumar Trivedi, Alice Branton, Dahryn Trivedi, Gopal Nayak, Barry Dean Wellborn, Deborah Lea Smith, Dezi Ann Koster, Elizabeth Patric, Jagdish Singh, Kathleen Starr Vagt, Krista Joanne Callas, Parthasarathi Panda, Kalyan Kumar Sethi, Snehasis Jana. Influence of the Consciousness Energy Healing Treatment on the Physicochemical, Spectral, Thermal and Behavioral Properties of Sodium Selenate. American Journal of Chemical Engineering. Vol. 5, No. 2, 2017, pp. 6-16. doi: 10.11648/j.ajche.20170502.11

Received: February 24, 2017; Accepted: March 9, 2017; Published: April 1, 2017

\begin{abstract}
Sodium selenate is an important nutraceutical/pharmaceutical compound used for the prevention and treatment of cancer, diabetes, inflammatory diseases, etc. The objective of the current study was to investigate the impact of The Trivedi Effect $^{\circledR}$ - Energy of Consciousness Healing Treatment (Biofield Energy Healing treatment) on physical, structural, thermal, and behavioral properties of sodium selenate using PXRD, PSD, FT-IR, UV-vis, TGA, and DSC analysis. Sodium selenate was divided into two parts - one part was control, while another part was treated with The Trivedi Effect ${ }^{\circledR}$ remotely by seven renowned Biofield Energy Healers and defined as The Trivedi Effect ${ }^{\circledR}$ Treated sample. The PXRD analysis showed a significant alteration of the crystallite size of the treated sample in the range of $-34.41 \%$ to $33.27 \%$ compared to the control sample. However, the average crystallite size of the treated sample was significantly decreased by $7.85 \%$ compared with the control sample. The particle size of the treated sample at $d_{10}, d_{50}$, and $d_{90}$ values were significantly reduced by $4.72 \%, 8.40 \%$, and $32.33 \%$, respectively compared with the control sample. Consequently, the surface area of the treated sample was significantly increased by $6.25 \%$ compared to the control sample. The control and treated FT-IR spectra indicated the presence of sharp and strong absorption bands at $886 \mathrm{~cm}^{-1}$ and $887 \mathrm{~cm}^{-1}$, respectively due to the Se=O stretching. The UV-vis spectroscopic analysis displayed that the wavelength for the maximum absorbance of the control and treated samples were at 204.6 and $204.9 \mathrm{~nm}$, respectively. TGA analysis revealed that the total weight loss of the treated sample was reduced significantly by $5.64 \%$ compared with the control sample. The DSC analysis showed that the treated sample $\left(94.63^{\circ} \mathrm{C}\right)$ had very close vaporization temperature than the control sample $\left(94.97^{\circ} \mathrm{C}\right)$. But, the latent heat of vaporization was increased significantly in the treated sample by $7.06 \%$ compared to the control sample. Thus, The Trivedi Effect ${ }^{\circledR}$ - Energy of Consciousness Healing Treatment might lead to generate a new polymorphic form of sodium selenate, which would be more soluble, bioavailable, and thermally stable compared with the untreated sample. The Trivedi Effect ${ }^{\circledR}$ treated sodium selenate would be very useful to design better nutraceutical/pharmaceutical formulations that might offer better therapeutic response against inflammatory diseases, immunological disorders, stress, aging, infectious diseases, cancer, diabetes, heart diseases, Alzheimer's disease, etc.
\end{abstract}

Keywords: Sodium Selenate, The Trivedi Effect ${ }^{\circledR}$, Consciousness Energy Healing Treatment, PXRD, Particle Size, Surface Area, TGA, DSC 


\section{Introduction}

Selenium (Se) is an essential trace nutrient in the human body. It plays an important role in various biological functions such as catalytic effect on the reaction of intermediate metabolism and inhibition of the toxic effect of heavy metals. Selenium is present in the active site of enzymes like glutathione peroxidase and also in around 30 proteins as selenocysteine. It is a potent antioxidant and is involved in the cellular defense against free radicals $[1,2]$. Hence, deficiency of selenium produces several disorders such as cancer, heart diseases, viral diseases, diabetes, infectious diseases, degenerative ailments, etc. As there is a very restricted range between essentiality and toxicity, a little bit high concentration of selenium can affect the human health such as loosing hair and nails, irritation of skin, eye, etc. [1-3]. The outcome of selenium is affected by numerous physical, chemical and biological factors, as these factors are related with the modifications in its oxidation state. It occurs naturally in four different oxidation states, i.e. $-2,0,+4$, and +6 . The different chemical forms of selenium can impact on its solubility and availability to organisms. Selenate is the most oxidized form among selenium compounds. It is less toxic and highly soluble in water [1-5]. Sodium selenate can be useful for the prevention and treatment of various ailments such as Alzheimer's disease, diabetes, etc. [6-8]. It is also used in the glass industry [9], an ingredient in some insecticides (against mites, aphids, and mealybugs) and some fungicides $[10,11]$. Sodium selenate can be used with vitamin $\mathrm{E}$ in the prevention of a many nutritional deficiency diseases. But, at high concentration, it causes cancers, deformation of hair and nails, giddiness, depression and nervousness [1]. Selenium methionine is a naturally occurring amino acid and is also the major nutritional source of selenium for the human body. After absorption in the body, inorganic forms of selenium undergo reductive metabolism giving $\mathrm{H}_{2} \mathrm{Se}$ responsible for the production of selenoproteins [12]. Therefore, sodium selenate was considered as one of the component in a novel proprietary herbomineral formulation for the source of selenium ion. This herbomineral formulation is designed as nutraceutical supplement, and can be used for the prevention and treatment of various human disorders.

The human body can discharge the electromagnetic waves in the form of bio-photons that surrounds the body. This electromagnetic energy is generated from the continuous movement of the electrically charged particles (ions, cells, etc.) inside the body. This is collectively known as Biofield. Biofield Energy Healing practitioners have the ability to harness the energy from the environment or the "universal energy field" and can transmit into any living or nonliving object(s) around the earth. The process, where the objects receive the Biofield Energy Treatment and respond into useful way is called as Biofield Energy Healing [13-15]. Biofield (Putative Energy Fields) based Energy Therapies are used worldwide to promote health and healing. The National
Center of Complementary and Integrative Health (NCCIH) has recognized and accepted Biofield Energy Healing as a Complementary and Alternative Medicine (CAM) health care approach in addition to other therapies, medicines and practices such as natural products, deep breathing, yoga, Tai Chi, Qi Gong, chiropractic/osteopathic manipulation, meditation, massage, special diets, homeopathy, progressive relaxation, guided imagery, acupressure, acupuncture, relaxation techniques, hypnotherapy, healing touch, movement therapy, pilates, rolfing structural integration, mindfulness, Ayurvedic medicine, traditional Chinese herbs and medicines, naturopathy, essential oils, aromatherapy, Reiki, cranial sacral therapy and applied prayer (as is common in all religions, like Christianity, Hinduism, Buddhism and Judaism) [16]. From the study on the various fields include materials science $[17,18]$, organic compounds [19-21], nutraceuticals [22, 23], pharmaceuticals [24, 25], microbiology [26-28], agricultural [29, 30], biotechnology [31-33], genetics [34, 35], it has been proven that Biofield Energy Healing (also known as The Trivedi Effect ${ }^{\mathbb{B}}$ ) has the astounding capability for alteration of the characteristic properties of the several non-living materials and living organisms. From the scientific literature, it has been found that the bioavailability of inorganic selenium is lower than the organic forms of selenium such as selenium methionine. But, selenium methionine is easily oxidized to methionine selenoxide, which is poorly absorbed from the gut of the human body [12]. The physicochemical properties such as particle size, crystalline structure, crystallite size, surface area, etc. of a drug play an important role in bioavailability, as these factors have direct influence on the absorption characteristic and stability of the drug [36]. The particle size, specific surface area, crystalline nature, chemical and thermal behavior of an atom/ion might be altered by the Biofield Energy Healing Treatment (The Trivedi Effect ${ }^{\mathbb{B}}$ ) through the possible mediation of neutrinos [37]. Literature mentioned that powder X-ray diffraction (PXRD), particle size distribution analysis (PSD), Fourier transform infrared (FTIR) spectrometry, ultraviolet-visible (UV-vis) spectroscopy, thermogravimetric analysis (TGA), and differential scanning calorimetry (DSC) analysis play an vital role for solving various problems encountered in industries for the pharmaceutical/nutraceutical formulation and developments [38]. Hence, the objective of the current study was to evaluate the effect of the Biofield Energy Healing Treatment on the physicochemical, spectral, and thermal properties of sodium selenate using various analytical techniques include PXRD, PSD, FT-IR spectrometry, UV-vis spectroscopy, TGA, and DSC.

\section{Materials and Methods}

\subsection{Chemicals and Reagents}

Sodium selenate was procured from Alfa Aesar, USA. All other chemicals used in the experiment were of analytical 
grade available in India.

\subsection{Energy of Consciousness Healing Treatment Strategies}

Sodium selenate was one of the components of the new proprietary herbomineral formulation, developed by our research team and it was used per se as the test compound for the current study. The test compound was divided into two parts, one part of the test compound did not receive any sort of treatment and was defined as the untreated or control sodium selenate sample. The second part of the test compound was treated with The Trivedi Effect ${ }^{\circledR}$ - Energy of Consciousness Healing Treatment (Biofield Energy Treatment) by a group of seven renowned Biofield Energy Healers remotely and was denoted as Biofield Energy Treated or The Trivedi Effect ${ }^{\circledR}$ sample. All seven Biofield Energy Healers were remotely located in the U.S.A., while the test compound was located in the research laboratory of GVK Biosciences Pvt. Ltd., Hyderabad, India. This Biofield Energy Treatment was provided for 5 minutes through Healer's Unique Energy Transmission process remotely to the test compound under the laboratory conditions. None of the Biofield Energy Healers in this study visited the laboratory in person, nor had any contact with the compounds. Similarly, the control compound was subjected to "sham" healers for 5 minutes, under the same laboratory conditions. The sham healer did not have any knowledge about The Trivedi Effect ${ }^{\circledR}$ - Energy of Consciousness Healing Treatment. After that, the treated and untreated samples were kept in similar sealed conditions and characterized thoroughly by PXRD, PSD, FT-IR, UV-visible spectroscopy, TGA, and DSC analysis.

\subsection{Characterization}

\subsubsection{Powder X-Ray Diffraction (PXRD) Analysis}

The XRD analysis was accomplished on PANalytical X'Pert Pro powder X-ray diffractometer system. The X-ray of wavelength $1.54056 \AA$ was used. The data was collected in the form of a chart of the Bragg angle $(2 \theta) v s$. intensity, and a detailed table containing information on peak intensity counts, d value $(\AA)$, relative intensity (\%), full width half maximum (FWHM) $\left(\theta^{\circ}\right)$. From the XRD results, the crystallite size $(G)$ was calculated using X'Pert data collector and X'Pert high score plus processing software. The crystallite size $(\mathrm{G})$ was calculated from the Scherrer equation $[39,40]$. The method was based on the width of the diffraction patterns obtained in the X-ray reflected the crystalline region. The crystallite size $(\mathrm{G})$ was calculated by using the following equation 1 :

$$
\mathrm{G}=\mathrm{k} \lambda /(\mathrm{b} \operatorname{Cos} \theta)
$$

Where, $\mathrm{k}$ is the equipment constant $(0.5), \lambda$ is the $\mathrm{X}$-ray wavelength $(0.154 \mathrm{~nm}) ; \mathrm{b}$ in radians is the full-width at half of the peaks and $\theta$ the corresponding Bragg angle.

Percent change in crystallite size $(\mathrm{G})$ was calculated using following equation 2 :
$\%$ change in crystallite size $=\frac{\left[G_{\text {Treated }}-G_{\text {Control }}\right]}{G_{\text {Control }}} \times 100$

Where, $G_{\text {Control }}$ and $G_{\text {Treated }}$ are the crystallite size of the control and Biofield Energy Treated samples, respectively.

A total of $\sim 500 \mathrm{mg}$ of the control and treated samples individually were used for the analysis and prepared by back loading technique using the sample preparation kit. The sample was spread on the holder ring in sufficient quantity to fill the ring cavity. It was then pressed down using powder press block and scrap the powder that was in surplus using a glass slide to get densely packed specimen. Consequently, the bottom plate was placed onto the holder ring and clamp in position. The sample holder was then removed from the sample preparation table by turning it upside down. A smooth surface of sample was obtained to ensure optimum results.

\subsubsection{Particle Size Distribution (PSD) Analysis}

The average particle size and particle size distribution were analyzed using Malvern Mastersizer 2000, UK with a detection range between $0.01 \mu \mathrm{m}$ to $3000 \mu \mathrm{m}$. The sample unit was filled with dispersant medium and operated the stirrer at $2500 \mathrm{rpm}$. Alignment of the optics was done and taken the background measurement. After the background measurement, the sample was added into the sample unit with constant monitoring the obscuration and stopped the addition of sample, when the obscuration reached in between $15 \%$ and $20 \%$. When the obscuration was stable, the measurement was taken twice and the average was taken of two measurements. The average histogram of the two measurements was recorded. Along with histogram, the data was presented in Table format which include particle size $(\mu \mathrm{m})$. Also, the values for particle size $(\mu \mathrm{m})$ for at below $10 \%$ level $\left(\mathrm{d}_{10}\right), 50 \%$ level $\left(\mathrm{d}_{50}\right)$, and $90 \%$ level $\left(\mathrm{d}_{90}\right)$ were calculated from the histogram and the calculations such as surface area $\left(\mathrm{m}^{2} / \mathrm{g}\right)$ were done by using software Mastersizer 2000.

Percent change in particle size (d) for at below $10 \%$ level $\left(\mathrm{d}_{10}\right), 50 \%$ level $\left(\mathrm{d}_{50}\right)$, and $90 \%$ level $\left(\mathrm{d}_{90}\right)$ was calculated using following equation 3 :

$$
\% \text { change in particle size }=\frac{\left[\mathrm{d}_{\text {Treated }}-\mathrm{d}_{\text {Control }}\right]}{\mathrm{d}_{\text {Control }}} \times 100
$$

Where, $d_{\text {Control }}$ and $d_{\text {Treated }}$ are the particle size $(\mu \mathrm{m})$ for at below 10\% level $\left(\mathrm{d}_{10}\right), 50 \%$ level $\left(\mathrm{d}_{50}\right)$, and $90 \%$ level $\left(\mathrm{d}_{90}\right)$ of the control and Biofield Energy Treated samples, respectively.

Percent change in surface area $(\mathrm{S})$ was calculated using following equation 4 :

$$
\% \text { change in surface area }=\frac{\left[\mathrm{S}_{\text {Treated }}-\mathrm{S}_{\text {Control }}\right]}{\mathrm{S}_{\text {Control }}} \times 100
$$

Where, $S_{\text {Control }}$ and $S_{\text {Treated }}$ are the surface area of the control and Biofield Energy Treated samples, respectively.

\subsubsection{Fourier Transform Infrared (FT-IR) Spectroscopy}

FT-IR spectroscopy of sodium selenate was performed on Spectrum two (Perkin Elmer, USA) Fourier transform infrared spectrometer with the frequency array of 400-4000 
$\mathrm{cm}^{-1}$ by using pressed $\mathrm{KBr}$ disk technique.

\subsubsection{Ultraviolet-Visible Spectroscopy (UV-Vis) Analysis}

The UV-Vis spectral analysis was carried out using Shimadzu UV-2450 with UV Probe, Japan. The spectrum was recorded using $1 \mathrm{~cm}$ quartz cell that has a slit width of $1.0 \mathrm{~nm}$. The wavelength range chosen for recording the spectra were $190-800 \mathrm{~nm}$. The absorbance spectra (in the range of 0.2 to 0.9 ) and wavelength of maximum absorbance $\left(\lambda_{\max }\right)$ were recorded.

\subsubsection{Thermal Gravimetric Analysis (TGA)}

TGA analysis was performed using Instrument TGA Q50 (TA Instruments, USA) at a heating rate of $10^{\circ} \mathrm{C} / \mathrm{min}$ from room temperature i.e. $30^{\circ} \mathrm{C}$ to $900^{\circ} \mathrm{C}$ under nitrogen the atmosphere (sample mass $\sim 15 \mathrm{mg}$ on the platinum pan). In TGA, the weight loss for each step was recorded in grams as well as in percent loss with respect to the initial weight. Also, the value of onset, endset, and peak temperature for each step were recorded in TGA. Percent change in weight loss (W) was calculated using following equation 5 :

$$
\% \text { change in weight loss }=\frac{\left[\mathrm{W}_{\text {Treated }}-\mathrm{W}_{\text {Control }}\right]}{\mathrm{W}_{\text {Control }}} \times 100
$$

$$
\% \text { change in latent heat of fusion }=\frac{\left[\Delta \mathrm{H}_{\text {Treated }}-\Delta \mathrm{H}_{\text {Control }}\right]}{\Delta \mathrm{H}_{\text {Control }}} \times 100
$$

Where, $\Delta \mathrm{H}_{\text {Control }}$ and $\Delta \mathrm{H}_{\text {Treated }}$ are the latent heat of fusion of the control and treated samples, respectively.

\section{Results and Discussion}

\subsection{Powder X-Ray Diffraction (PXRD) Analysis}

The PXRD diffractograms of the both control and treated
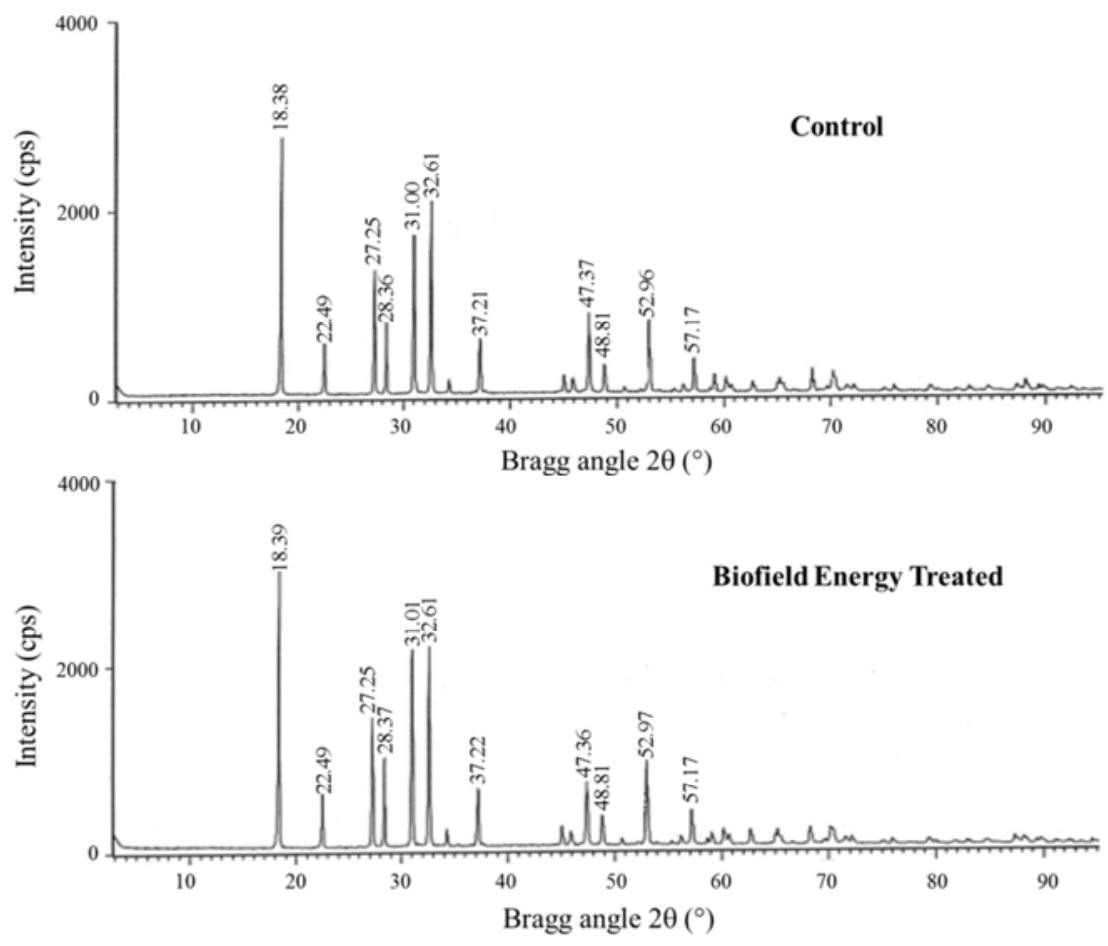

Figure 1. PXRD diffractograms of the control and Biofield Energy Treated sodium selenate. sodium selenate (Figure 1) showed very sharp and intense peaks indicating that both these samples were crystalline in nature. PXRD data such as Bragg angle (20), relative intensity (\%), full width half maximum (FWHM) $\left(\theta^{\circ}\right)$, and crystallite size $(\mathrm{G})$ for the control and treated sodium selenate are presented in Table 1 . The crystallite size was calculated by the help of Scherrer equation $[39,40]$.
Where, $\mathrm{W}_{\text {Control }}$ and $\mathrm{W}_{\text {Treated }}$ are the weight loss of the

Analysis was performed using the DSC Q20 (TA Instruments, USA) differential scanning calorimeter. $\sim 5 \mathrm{mg}$ equilis rate of $10^{\circ} \mathrm{C} / \mathrm{min}$ under nitrogen gas as purge atmosphere with the flow rate of $50 \mathrm{~mL} / \mathrm{min}$. The value for onset, endset, peak temperature, peak height $(\mathrm{mJ}$ or $\mathrm{mW})$, peak area, and change in melting point $(\mathrm{T})$ was calculated using following equation 6:

$\%$ change in melting point $=\frac{\left[\mathrm{T}_{\text {Treated }}-\mathrm{T}_{\text {Control }}\right]}{\mathrm{T}_{\text {Control }}} \times 100$

Where, $\mathrm{T}_{\text {Control }}$ and $\mathrm{T}_{\text {Treated }}$ are the melting point of the control and treated samples, respectively.

calculated using following equation 7 : 2.3.6. Differential Scanning Calorimetry (DSC) 
Table 1. PXRD data for the control and Biofield Energy Treated sodium selenate.

\begin{tabular}{|c|c|c|c|c|c|c|c|c|c|}
\hline \multirow{2}{*}{$\begin{array}{l}\text { Entry } \\
\text { No. }\end{array}$} & \multicolumn{2}{|c|}{ Bragg angle $\left({ }^{\circ} 2 \theta\right)$} & \multicolumn{2}{|c|}{ Relative Intensity (\%) } & \multicolumn{2}{|c|}{ FWHM $\left({ }^{\circ} 2 \theta\right)$} & \multicolumn{3}{|c|}{ Crystallite size $(\mathrm{G}, \mathrm{nm})$} \\
\hline & Control & Treated & Control & Treated & Control & Treated & Control & Treated & \% change" \\
\hline 1 & 18.38 & 18.39 & 100.00 & 100.00 & 0.0836 & 0.0836 & 53.34 & 53.34 & 0.00 \\
\hline 2 & 22.49 & 22.49 & 19.97 & 19.34 & 0.1171 & 0.1171 & 38.33 & 38.33 & 0.00 \\
\hline 3 & 27.25 & 27.25 & 48.04 & 46.92 & 0.1338 & 0.1004 & 33.85 & 45.12 & 33.27 \\
\hline 4 & 28.36 & 28.37 & 27.40 & 31.83 & 0.1004 & 0.1004 & 45.23 & 45.23 & 0.00 \\
\hline 5 & 31.00 & 31.01 & 61.79 & 71.62 & 0.1004 & 0.1171 & 45.50 & 39.02 & -14.26 \\
\hline 6 & 32.61 & 32.61 & 73.46 & 72.52 & 0.0669 & 0.1020 & 68.57 & 44.97 & -34.41 \\
\hline 7 & 37.21 & 37.22 & 21.68 & 20.75 & 0.1506 & 0.1632 & 30.85 & 28.47 & -7.72 \\
\hline 8 & 47.37 & 47.36 & 30.74 & 22.40 & 0.0816 & 0.1020 & 58.93 & 47.14 & -20.00 \\
\hline 9 & 48.81 & 48.81 & 10.73 & 10.91 & 0.1020 & 0.1171 & 47.41 & 41.30 & -12.89 \\
\hline 10 & 52.96 & 52.97 & 27.88 & 30.70 & 0.1428 & 0.1428 & 34.46 & 34.46 & 0.00 \\
\hline 11 & 57.17 & 57.17 & 12.74 & 12.58 & 0.1224 & 0.1224 & 40.98 & 40.98 & 0.00 \\
\hline 12 & \multicolumn{6}{|c|}{ Average crystallite size* } & 45.22 & 41.67 & -7.85 \\
\hline
\end{tabular}

FWHM: Full width half maximum, ${ }^{*}$ denotes the percentage change in the crystallite size of Biofield Energy Treated sample with respect to the control sample.

The diffractograms showed the notable changes of the crystallite size of the treated sodium selenate compared with the control sample. From Table 1 (entry 1), the most intense peaks for the control and treated samples were found at $2 \theta$ equal to $18.38^{\circ}$ and 18.89 , respectively. The crystallite size of the Biofield Energy Treated sodium selenate at $2 \theta$ equal to nearly $27.3^{\circ}$ (Table 1 , entry 3 ) was significantly increased by $33.27 \%$ with respect to the control sample. In contrast, at position $2 \theta$ equal to nearly $31.0^{\circ}, 32.6^{\circ}, 37.2^{\circ}, 47.4^{\circ}$, and $48.8^{\circ}$ (Table 1 , entry 5-9), and the crystallite size values of the Biofield Energy Treated samples were markedly decreased in the range of $7.72 \%$ to $34.41 \%$ in comparison to the control sample. But, the crystallite size of the control and Biofield Energy Treated sodium selenate at $2 \theta$ equal to nearly $18.4^{\circ}, 22.5^{\circ}, 28.4^{\circ}, 52.9$, and $57.2^{\circ}$ (Table 1 , entry 1 , $2,4,10$, and 11) were the same value. Overall, the average crystallite size of the Biofield Energy Treated sodium selenate was significantly decreased by $7.85 \%$ compared with the control sample. Beside these, other XRD parameters such as relative intensities of the PXRD peaks in the Biofield Energy Treated sodium selenate were significantly changed compared to the control sample. It has been reported that XRD relative intensity of each diffraction face on crystalline compound changes according to the crystal morphology [41]. Literature demonstrated that alterations in the XRD pattern provide the proof of polymorphic transitions [42-44]. Hence, changes in the crystallite size and relative intensities of XRD peaks revealed that the crystal morphology of the Biofield Energy Treated sample was modified from the control sample. Thus, it is anticipated that the change in the crystal morphology of the sodium selenate was due to the energy transferred through Biofield Energy Healing (The Trivedi Effect $\left.{ }^{\circledR}\right)$ and this probably introduced a new polymorphic form of sodium selenate. Crystal habit, size and even polymorphic form of a drug have an important effect on drug solubility, dissolution, and bioavailability. Numerous examples in the scientific literature establish the impacts of alteration in crystal morphology on in vitro dissolution rate, with prospective for improving bioavailability [45]. Thus, it is inferred that The Trivedi Effect ${ }^{\circledR}$ - Energy of Consciousness Healing Treatment might help for improving the bioavailability of sodium selenate.

\subsection{Particle Size Distribution (PSD) Analysis}

Particle size $\left(\mathrm{d}_{10}, \mathrm{~d}_{50}\right.$, and $\left.\mathrm{d}_{90}\right)$ and surface area of both the control and Biofield Energy Treated sodium selenate were explored and the results are presented in Table 2. The particle size values of the control sodium selenate at $\mathrm{d}_{10}, \mathrm{~d}_{50}$, and $\mathrm{d}_{90}$ were $5.09 \mu \mathrm{m}, 24.76 \mu \mathrm{m}$, and $95.13 \mu \mathrm{m}$, respectively. The particle size values at $d_{10}, d_{50}$, and $d_{90}$ of the Biofield Energy Treated sodium selenate were $4.85 \mu \mathrm{m}, 22.68 \mu \mathrm{m}$, and 64.37 $\mu \mathrm{m}$, respectively. Thus, the particle size values at $\mathrm{d}_{10}, \mathrm{~d}_{50}$, and $\mathrm{d}_{90}$ of the Biofield Energy Treated sodium selenate were significantly reduced by $4.72 \%, 8.40 \%$, and $32.33 \%$, respectively with respect to the control sample. The surface area analysis demonstrated that the surface area of the Biofield Energy Treated sodium selenate $\left(0.51 \mathrm{~m}^{2} / \mathrm{g}\right)$ was significantly increased by $6.25 \%$ compared with the control sample $\left(0.48 \mathrm{~m}^{2} / \mathrm{g}\right)$.

Table 2. Particle size data $\left(d_{10}, d_{50}\right.$, and $\left.d_{90}\right)$ and surface area of the control and Biofield Energy Treated sodium selenate.

\begin{tabular}{lllll}
\hline Parameter & $\mathbf{d}_{\mathbf{1 0}}(\boldsymbol{\mu m})$ & $\mathbf{d}_{\mathbf{5 0}}(\boldsymbol{\mu m})$ & $\mathbf{d}_{\mathbf{9 0}}(\boldsymbol{\mu \mathbf { m } )})$ & $\begin{array}{l}\text { Surface area } \\
\left(\mathbf{m}^{\mathbf{2}} / \mathbf{g}\right)\end{array}$ \\
\hline Control & 5.09 & 24.76 & 95.13 & 0.48 \\
Biofield Treated $^{*}$ & 4.85 & 22.68 & 64.37 & 0.51 \\
Percent change $^{(\%)}$ & -4.72 & -8.40 & -32.33 & 6.25 \\
\hline
\end{tabular}

* denotes the percentage change in the particle size data $\left(\mathrm{d}_{10}, \mathrm{~d}_{50}\right.$, and $\left.\mathrm{d}_{90}\right)$ and surface area of Biofield Energy Treated sample with respect to the control sample.

The particle size, shape and surface area of the compound plays a vital role in the solubility, absorption, dissolution and bioavailability of the pharmaceuticals [36, 46, 47]. Reduction in particle size and higher surface area enhance the solubility of the solid particles as well as increase the dissolution rate and bioavailability [48]. Thus, it is predicted that The Trivedi Effect $^{\circledR}$ - Energy of Consciousness Healing Treatment sodium selenate might be absorbed in faster rate from the gut and thus, can offer more bioavailability than the untreated sample.

\subsection{Fourier Transform Infrared (FT-IR) Spectroscopy}

The FT-IR spectra of both the control and Biofield Energy 
Treated samples of sodium selenate are exhibited in Figure 2. The scientific literature reported that the water molecules which are incorporated into the lattice structure of the crystalline inorganic compounds harvest the characteristic absorption bands in the $3800-3200 \mathrm{~cm}^{-1}$ and $1700-1600 \mathrm{~cm}^{-1}$ regions due to the $\mathrm{O}-\mathrm{H}$ stretching and bending for the water molecules, respectively [49]. The control IR spectrum displayed the $\mathrm{O}-\mathrm{H}$ stretching and bending absorption bands at 3441, 1780, and $1706 \mathrm{~cm}^{-1}$, respectively. In addition, peaks for the O-H stretching and bending of the water molecules in the Biofield Energy Treated sample were found at 3436,
1775 , and $1628 \mathrm{~cm}^{-1}$. The fingerprint region of the Biofield Energy Treated and control samples was remained unchanged. From the literature, it has been found that $\mathrm{M}=\mathrm{O}$ (metal-oxide) stretching absorption band for inorganic materials was found in the $1010-850 \mathrm{~cm}^{-1}$ region [49]. A sharp and strong absorption bands at $886 \mathrm{~cm}^{-1}$ due to the $\mathrm{Se}=\mathrm{O}$ stretching were found in the spectrum of the control sample, while Biofield Energy Treated sample exhibited this peak at $887 \mathrm{~cm}^{-1}$. The analysis indicated that structure of the Biofield Energy Treated sodium selenate was remained same with respect to the control sample.
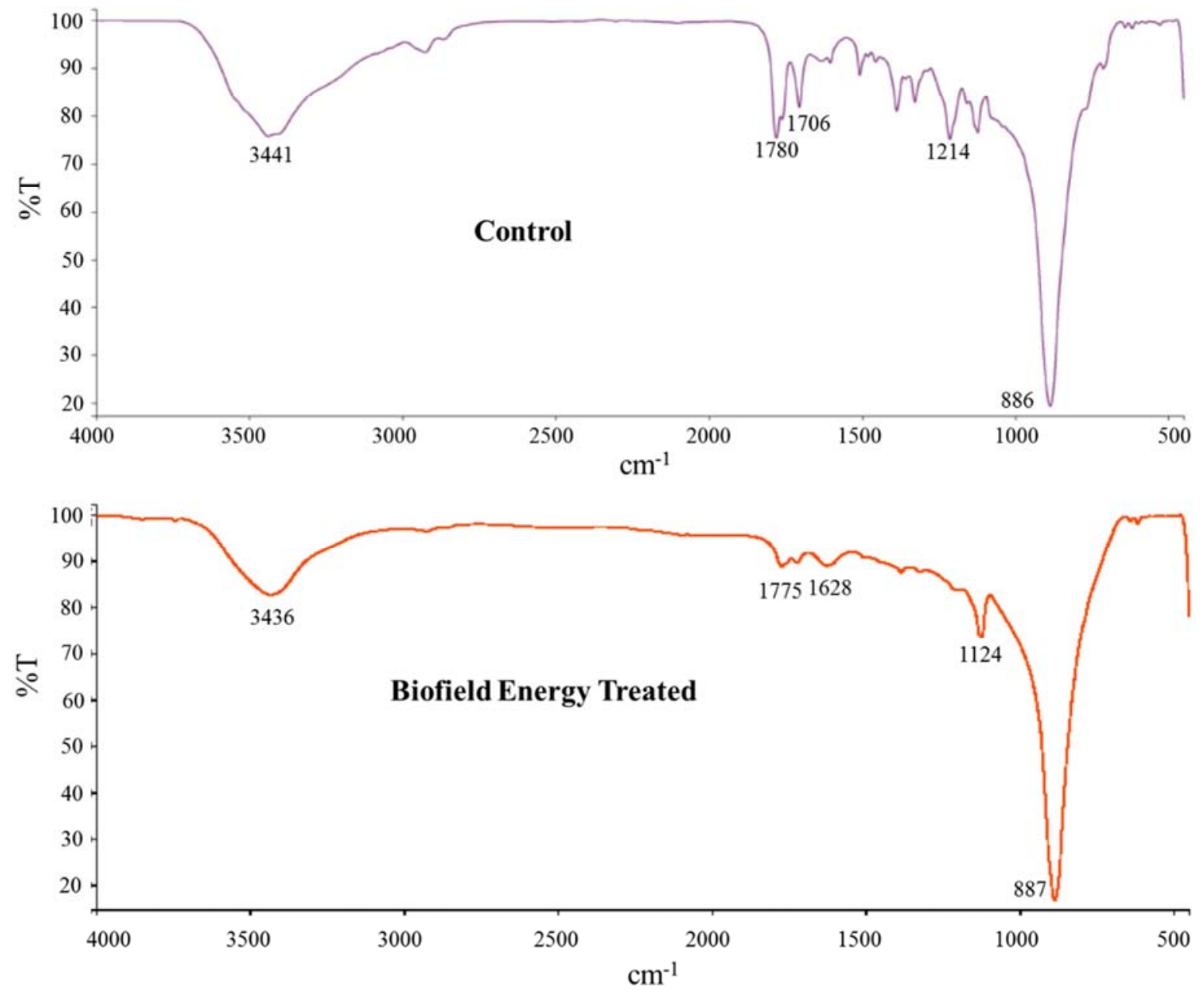

Figure 2. FT-IR spectra of the control and Biofield Energy Treated sodium selenate.

\subsection{Ultraviolet-Visible Spectroscopy (UV-Vis) Analysis}

The UV-visible spectra of both the control and Biofield Energy Treated sodium selenate are shown in Figure 3. The wavelength of the maximum absorbance $\left(\lambda_{\max }\right)$ of the control and treated sodium selenate were at 204.6 and $204.9 \mathrm{~nm}$, respectively and there was a minor shift of absorbance maxima from 2.5675 in control sample to 2.5658 in the treated sample. However, the $\lambda_{\max }$ of the treated sample remained unchanged compared with the control sample. The UV absorbance happens due to the different type of energy transitions from the singlet to the singlet excited state such as $\sigma \rightarrow \sigma^{*}, \mathrm{n} \rightarrow \pi^{*}$, and $\pi \rightarrow \pi^{*}$. These type of electronic transitions occur when the difference in energy between the lowest unoccupied molecular orbital (LUMO) and the highest occupied molecular orbital (HOMO) is significantly greater than the activation energy of the compound [50]. As. there was no change in the $\lambda_{\max }$ of the treated sample as compared to the control, it is anticipated that the structural configuration or activation energy of sodium selenate remained unchanged due to The Trivedi Effect ${ }^{\circledR}$ - Energy of Consciousness Healing Treatment. 


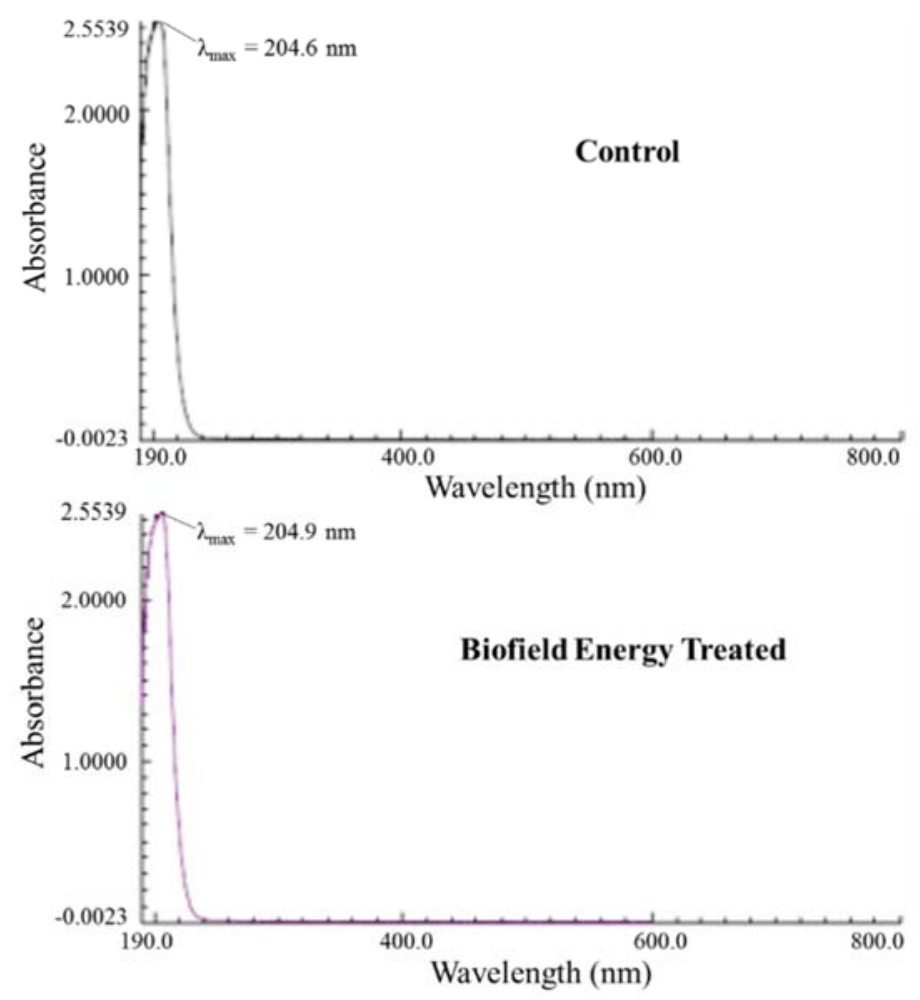

Figure 3. UV-vis spectra of the control and Biofield Energy Treated sodium selenate.

\subsection{Thermal Gravimetric Analysis (TGA)}

The thermal stability of a solid compound plays an important role in the quality, efficacy, and safety in a drug formulation during the manufacturing process, shipment, storage, and handling [51]. Hence, TGA and DSC analysis were used to examine the thermal stability of both the control and treated sodium selenate. The TGA thermograms of both the control and treated samples and their thermal analysis data are shown in Figure 4. The TGA analysis showed one steps of thermal degradation of sodium selenate.
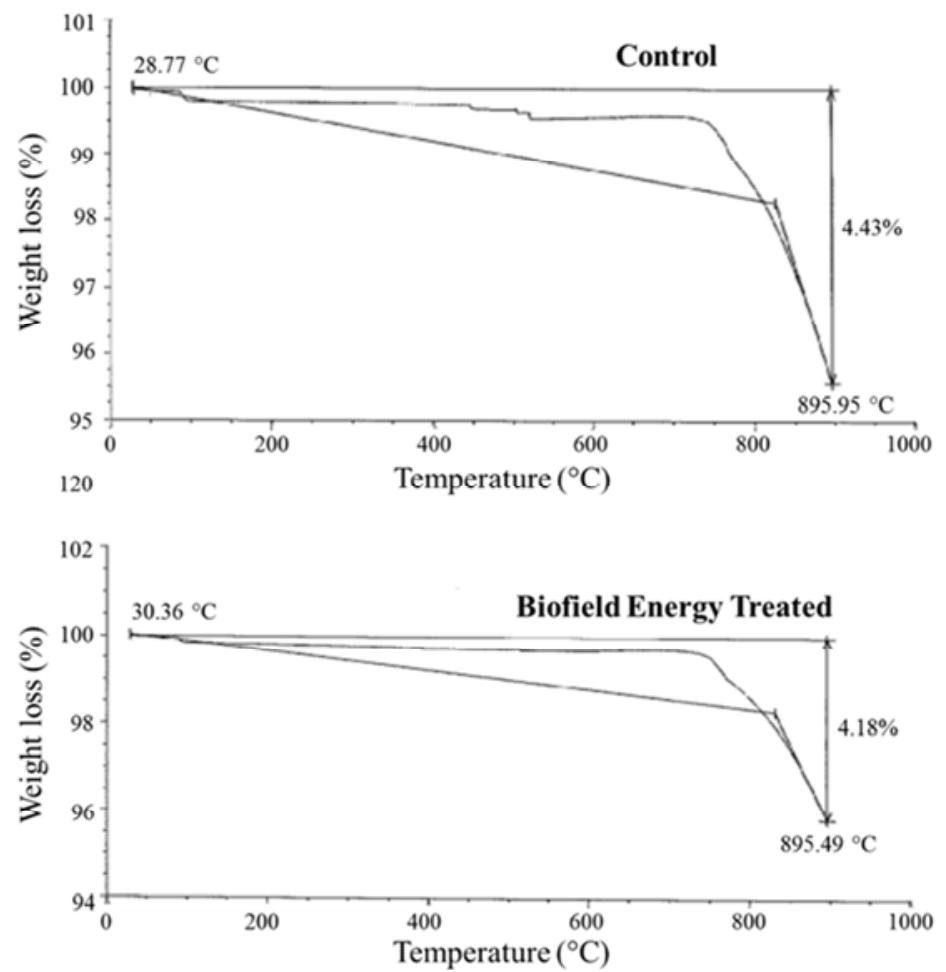

Figure 4. TGA thermograms of the control and Biofield Energy Treated sodium selenate. 
The TGA thermogram of the control sample exhibited $4.43 \%$ weight loss from $28.77^{\circ} \mathrm{C}$ to $895.95^{\circ} \mathrm{C}$. Consequently, the TGA thermogram of the Biofield Energy Treated sample showed $4.18 \%$ weight loss from $30.36^{\circ} \mathrm{C}$ to $895.49^{\circ} \mathrm{C}$. The weight loss of the treated sample was significantly reduced by $5.64 \%$ compared with the control sample. Thus, it is assumed that The Trivedi Effect ${ }^{\circledR}$ - Energy of Consciousness Healing Treatment might improve the thermal stability of sodium selenate.

\subsection{Differential Scanning Calorimetry (DSC) Analysis}

The DSC thermograms of both the control and Biofield Energy Treated sodium selenate are shown in Figure 5 and their DSC data are depicted in Table 3. The DSC thermogram of the control sample showed the presence of a sharp endothermic inflection at $94.97^{\circ} \mathrm{C}$ which was due to evaporation of the bound water and the latent heat of vaporization $\left(\Delta \mathrm{H}_{\text {vaporization }}\right)$ was $4.39 \mathrm{~J} / \mathrm{g}$. Consequently, the Biofield Energy Treated sodium selenate showed this endothermic peak at $94.63^{\circ} \mathrm{C}$ along with a latent heat of vaporization $\left(\Delta \mathrm{H}_{\text {vaporization }}\right)$ of $4.70 \mathrm{~J} / \mathrm{g}$. This suggested that the temperature of the evaporation of the bound water in the Biofield Energy Treated sample was slightly (0.21\%) decreased, whereas the $\Delta \mathrm{H}_{\text {vaporization }}$ was increased significantly by $7.06 \%$ compared to the control sample.
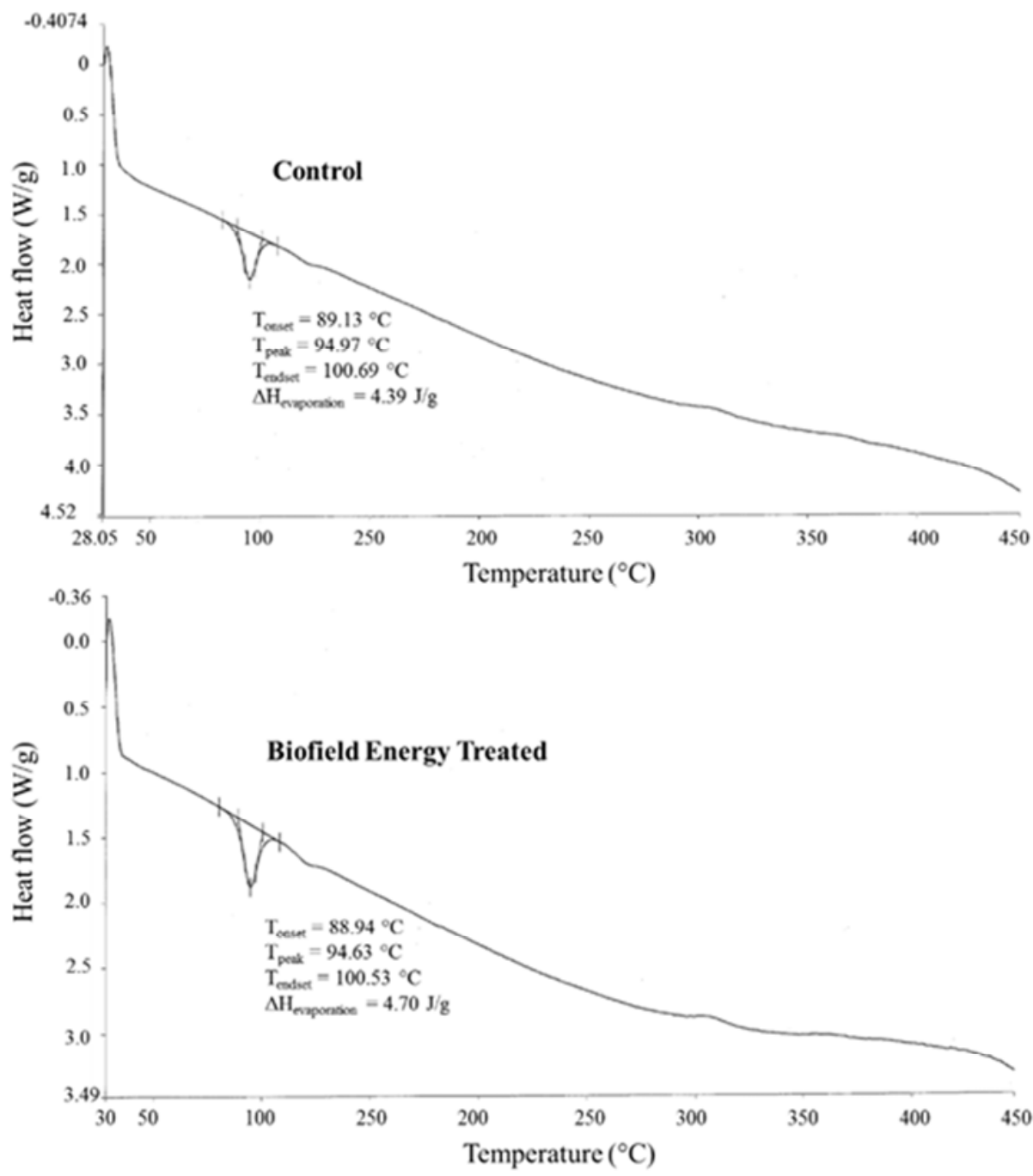

Figure 5. DSC thermograms of the control and Biofield Energy Treated sodium selenate.

Table 3. Comparison of DSC data between the control and Biofield Energy Treated sodium selenate.

\begin{tabular}{lllll}
\hline Sample & $\begin{array}{l}\text { Onset vaporization } \\
\text { temperature }\left(\mathbf{T}_{\text {onset }}\right){ }^{\circ} \mathbf{C}\end{array}$ & $\begin{array}{l}\text { Peak vaporization } \\
\text { temperature }\left(\mathbf{T}_{\text {peak }}\right){ }^{\circ} \mathbf{C}\end{array}$ & $\begin{array}{l}\text { Endset vaporization } \\
\text { temperature }\left(\mathbf{T}_{\text {endset }}\right){ }^{\circ} \mathbf{C}\end{array}$ & $\begin{array}{l}\text { Latent heat of vaporization } \\
\left(\Delta \mathbf{H}_{\text {vaporization }}\right) \mathbf{J} / \mathbf{g}\end{array}$ \\
\hline Control & 99.13 & 94.97 & 100.53 & 4.39 \\
Biofield Energy Treated & 88.94 & 94.63 & 100.53 & 4.70 \\
\% Change $^{*}$ & -0.21 & -0.36 & 0.00 & 7.06 \\
\hline
\end{tabular}

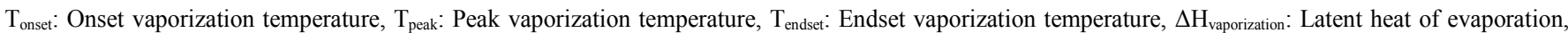
*denotes the percentage change of Biofield Energy Treated sample with respect to the control sample. 


\section{Conclusions}

The current analysis revealed that The Trivedi Effect ${ }^{\circledR}$ Energy of Consciousness Healing Treatment (Biofield Energy Healing Treatment) displayed the significant impact on the physicochemical and thermal properties of sodium selenate. The PXRD analysis showed the remarkable alteration of the crystallite size of the treated sample from $-34.41 \%$ to $33.27 \%$ compared with the control sample. Overall, the average crystallite size of the treated sodium selenate was significantly decreased by $7.85 \%$ compared with the control sample. This result indicated that the crystal morphology of the treated sodium selenate was changed from the control sample and The Trivedi Effect ${ }^{\circledR}$ - Biofield Energy Healing might lead to a new polymorphic form of sodium selenate. The particle size of the Biofield Energy Treated sample at $\mathrm{d}_{10}, \mathrm{~d}_{50}$, and $\mathrm{d}_{90}$ values were significantly decreased by $4.72 \%, 8.40 \%$, and $32.33 \%$, respectively compared with the control sample. Similarly, the surface area of the treated sample was significantly increased by $6.25 \%$ compared with the control sample. TGA analysis revealed that the total weight loss of the Biofield Energy Treated sample was reduced by $4.93 \%$ compared with the control sample. The DSC analysis revealed that the treated sample $\left(95.10^{\circ} \mathrm{C}\right)$ had higher vaporization temperature than the control sample $\left(94.80^{\circ} \mathrm{C}\right)$. The latent heat of vaporization was increased significantly in the Biofield Energy Treated sample by $7.06 \%$ compared to the control sample. Briefly, the Biofield Energy Treated sodium selenate might be a new polymorphic form (i.e. enantiotropic) of sodium selenate having reduced crystallite and particle size and increased surface area. Thus, The Trivedi Effect ${ }^{\circledR}$ treated sodium selenate could be more soluble, bioavailable, and thermally stable than the control sample. Hence, The Trivedi Effect ${ }^{\mathbb{B}}$ treated sodium selenate would be very useful to design better nutraceutical and/or pharmaceutical formulations that might offer better therapeutic response against various diseases such as diabetes mellitus, allergies, and septic shock; stress-related disorders like sleep disorder, insomnia, anxiety, depression, Attention Deficit Disorder (ADD), Attention Deficit Hyperactive Disorder (ADHD), mental restlessness (mind chattering), brain frog, low libido, impotency, lack of motivation, mood swings, fear of the future, confusion, migraines, headaches, forgetfulness, overwhelm, loneliness, worthlessness, indecisiveness, frustration, irritability, chronic fatigue, obsessive/compulsive behavior and panic attacks; inflammatory diseases and immunological disorders like Lupus, Systemic Lupus Erythematosus, Hashimoto Thyroiditis, Type 1 Diabetes, Asthma, Chronic peptic ulcers, Tuberculosis, Hepatitis, Chronic active hepatitis, Celiac Disease (gluten-sensitive enteropathy), Addison Disease, Crohn's disease, Graves' Disease, Pernicious and Aplastic Anemia, Sjogren Syndrome, Irritable Bowel Syndrome (IBS), Multiple Sclerosis, Rheumatoid arthritis, Chronic periodontitis, Ulcerative colitis, Chronic sinusitis, Myasthenia Gravis, Atherosclerosis, Vasculitis, Dermatitis, Diverticulitis, Rheumatoid Arthritis, Reactive Arthritis, Alopecia Areata, Psoriasis, Scleroderma,
Fibromyalgia, Chronic Fatigue Syndrome and Vitiligo; agingrelated diseases like cardiovascular disease, arthritis, cancer, Alzheimer's disease, dementia, cataracts, osteoporosis, diabetes, hypertension, glaucoma, hearing loss, Parkinson's Disease, Huntington's Disease, Prion Disease, Motor Neurone Disease, Spinocerebellar Ataxia, Spinal muscular atrophy, Amyotrophic lateral sclerosis, Friedreich's Ataxia, Lewy Body Disease, chronic infections and much more.

\section{Abbreviations}

DSC: Differential scanning calorimetry, FT-IR: Fourier transform infrared spectroscopy, FWHM: Full width half maximum, G: Crystallite size, HOMO: Highest energy occupied molecular orbital, LUMO: Lowest energy unoccupied molecular orbital, TGA: Thermal gravimetric analysis, $\mathrm{T}_{\text {onset }}$ : Onset melting temperature, $\mathrm{T}_{\text {peak }}$ : Peak melting temperature, $\mathrm{T}_{\text {endset }}$ : Endset melting temperature, $\Delta \mathrm{H}_{\text {vaporization: }}$ Latent heat of vaporization, UV-vis: Ultravioletvisible spectroscopy, PSD: Particle size distribution, PXRD: Powder X-ray diffraction.

\section{Acknowledgements}

The authors gratefully acknowledged to GVK Biosciences Pvt. Ltd., Trivedi Science, Trivedi Global, Inc. and Trivedi Master Wellness for the assistance and support during the work.

\section{References}

[1] Basnayake RST (2001) Inorganic selenium and tellurium speciation in aqueous medium of biological samples, Master of Science (Chemistry), December 2001, Sam Houston State University, Huntsville, Texas, $60 \mathrm{pp}$.

[2] Soruraddin MH, Heydari R, Puladvand M, Zahedi MM. (2011) A. new spectrophotometric method for determination of selenium in cosmetic and pharmaceutical preparations after preconcentration with cloud point extraction. Int J. Anal Chem 2011: 729651.

[3] UmyFsová D, Vítová M, Doušková I, Bišová K, Hlavová M, Č́žková M, Machát J, Doucha J, Zachleder V. (2009) Bioaccumulation and toxicity of selenium compounds in the green alga Scenedesmus quadricauda. BMC Plant Biol 9: 58.

[4] Gonzalez CM, Hernandez J, Peralta-Videa JR, Botez CE, Parsons JG, Gardea-Torresdey JL. (2012) Sorption kinetic study of selenite and selenate onto a high and low pressure aged iron oxide nanomaterial. J. Hazard Mater 211-212: 138145 .

[5] Sabaty M, Avazeri C, Pignol D, Vermeglio A. (2001) Characterization of the reduction of selenate and tellurite by nitrate reductases. Appl Environ Microbiol 67: 5122-5126.

[6] Van Eersel J, Ke YD, Liu X, Delerue F, Kril JJ, Götz J, Ittner LM. (2010) Sodium selenate mitigates tau pathology, neurodegeneration, and functional deficits in Alzheimer's disease models. Proc Natl Acad Sci USA 107: 13888-13893. 
[7] Salama RM, Schaalan MF, Elkoussi AA, Khalifa AE. (2013) Potential utility of sodium selenate as an adjunct to metformin in treating type II diabetes mellitus in rats: A. perspective on protein tyrosine phosphatase. Biomed Res Int 2013: 231378.

[8] Ryan-Harshman M, Aldoori W. (2005) The relevance of selenium to immunity, cancer, and infectious/inflammatory diseases. Can J. Diet Pract Res 66: 98-102.

[9] https://en.wikipedia.org/wiki/Sodium_selenate.

[10] Krieger RI. (2001) Handbook of Pesticide Toxicology, $2^{\text {nd }}$ Edn, Volume 1; Academic Press: San Diego, CA.

[11] Hanson B, Lindblom SD, Loeffler ML, Pilon-Smits E. (2004) Selenium protects plants from phloem-feeding aphids due to both deterrence and toxicity. New Phytologist 162: 655-662.

[12] Haug A, Graham RD, Christophersen OA, Lyons GH. (2007) How to use the world's scarce selenium resources efficiently to increase the selenium concentration in food. Microb Ecol Health Dis 19: 209-228.

[13] Rubik B. (2002) The biofield hypothesis: Its biophysical basis and role in medicine. J. Altern Complement Med 8: 703-717.

[14] Nemeth L (2008) Energy and biofield therapies in practice. Beginnings 28: 4-5.

[15] Rivera-Ruiz M, Cajavilca C, Varon J. (2008) Einthoven's string galvanometer: The first electrocardiograph. Tex Heart Inst J. 35: 174-178.

[16] Koithan M. (2009) Introducing complementary and alternative therapies. J. Nurse Pract 5: 18-20.

[17] Trivedi MK, Branton A, Trivedi D, Nayak G, Sethi KK, Jana S. (2016) Isotopic abundance ratio analysis of biofield energy treated indole using gas chromatography-mass spectrometry. Science Journal of Chemistry 4: 41-48.

[18] Trivedi MK, Branton A, Trivedi D, Nayak G, Panda P, Jana S. (2016) Evaluation of the isotopic abundance ratio in biofield energy treated resorcinol using gas chromatography-mass spectrometry technique. Pharm Anal Acta 7: 481.

[19] Trivedi MK, Branton A, Trivedi D, Nayak G, Bairwa K, Jana S. (2015) Fourier transform infrared and ultraviolet-visible spectroscopic characterization of ammonium acetate and ammonium chloride: An impact of biofield treatment. Mod Chem appl 3: 163.

[20] Trivedi MK, Branton A, Trivedi D, Nayak G, Bairwa K, Jana S. (2015) Spectroscopic characterization of disodium hydrogen orthophosphate and sodium nitrate after biofield treatment. J. Chromatogr Sep Tech 6: 282.

[21] Trivedi MK, Branton A, Trivedi D, Nayak G, Bairwa K, Jana S. (2015) Impact of biofield treatment on spectroscopic and physicochemical properties of $p$-nitroaniline. Insights in Analytical Electrochemistry 1: 1-8.

[22] Trivedi MK, Tallapragada RM, Branton A, Trivedi D, Nayak G, Latiyal O, Mishra RK, Jana S. (2015) Physicochemical characterization of biofield treated calcium carbonate powder. American Journal of Health Research 3: 368-375.

[23] Trivedi MK, Tallapragada RM, Branton A, Trivedi D, Nayak G, Latiyal O, Jana S. (2015) Physical, atomic and thermal properties of biofield treated lithium powder. J Adv Chem Eng 5: 136.
[24] Trivedi MK, Branton A, Trivedi D, Nayak G, Mondal SC, Jana S. (2015) In vitro evaluation of biofield treatment on viral load against human immunodeficiency-1 and cytomegalo viruses. American Journal of Health Research. 3: 338-343.

[25] Trivedi MK, Patil S, Shettigar H, Bairwa K, Jana S. (2015) Phenotypic and biotypic characterization of Klebsiella oxytoca: An impact of biofield treatment. J. Microb Biochem Technol 7: 203-206.

[26] Trivedi MK, Branton A, Trivedi D, Shettigar H, Nayak G, Gangwar M, Jana S. (2015) Assessment of antibiogram of multidrug-resistant isolates of enterobacter aerogenes after biofield energy treatment. J. Pharma Care Health Sys 2: 145.

[27] Trivedi MK, Patil S, Shettigar H, Mondal SC, Jana S. (2015) In vitro evaluation of biofield treatment on Enterobacter cloacae: Impact on antimicrobial susceptibility and biotype. J Bacteriol Parasitol 6: 241.

[28] Trivedi MK, Patil S, Shettigar H, Mondal SC, Jana S. (2015) Evaluation of biofield modality on viral load of Hepatitis B. and C. viruses. J. Antivir Antiretrovir 7: 083-088.

[29] Trivedi MK, Branton A, Trivedi D, Nayak G, Gangwar M, Jana S. (2015) Effect of biofield energy treatment on chlorophyll content, pathological study, and molecular analysis of cashew plant (Anacardium occidentale L.). Journal of Plant Sciences. 3: 372-382.

[30] Trivedi MK, Branton A, Trivedi D, Nayak G, Mondal SC, Jana S. (2015) Morphological characterization, quality, yield and DNA fingerprinting of biofield treated alphonso mango (Mangifera indica L.). Journal of Food and Nutrition Sciences 3: $245-250$.

[31] Trivedi MK, Branton A, Trivedi D, Nayak G, Bairwa K, Jana S. (2015) Physical, thermal, and spectroscopic characterization of biofield energy treated murashige and skoog plant cell culture media. Cell Biology 3: 50-57.

[32] Trivedi MK, Branton A, Trivedi D, Nayak G, Mishra RK, Jana S. (2015) Characterization of physical, thermal and spectral properties of biofield treated date palm callus initiation medium. International Journal of Nutrition and Food Sciences 4: 660-668.

[33] Trivedi MK, Branton A, Trivedi D, Nayak G, Mishra RK, Jana S. (2015) Comparative physicochemical evaluation of biofield treated phosphate buffer saline and hanks balanced salt medium. American Journal of BioScience 3: 267-277.

[34] Trivedi MK, Patil S, Shettigar H, Bairwa K, Jana S. (2015) Evaluation of phenotyping and genotyping characterization of Serratia marcescens after biofield treatment. J. Mol Genet Med 9: 179.

[35] Trivedi MK, Branton A, Trivedi D, Nayak G, Charan S, Jana S. (2015) Phenotyping and 16S rDNA analysis after biofield treatment on Citrobacter braakii: A. urinary pathogen. J Clin Med Genom 3: 129.

[36] Chereson R. (2009) Bioavailability, bioequivalence, and drug selection. In: Makoid CM, Vuchetich PJ, Banakar UV (Eds) Basic pharmacokinetics ( $1^{\text {st }}$ Edn) Pharmaceutical Press, London.

[37] Trivedi MK, Mohan TRR (2016) Biofield energy signals, energy transmission and neutrinos. American Journal of Modern Physics 5: 172-176. 
[38] Chauhan A, Chauhan P. (2014) Powder XRD technique and its applications in science and technology. J. Anal Bioanal Tech 5: 212.

[39] Alexander L, Klug HP. (1950) Determination of crystallite size with the X-Ray Spectrometer. J App Phys 21: 137.

[40] Langford JI, Wilson AJC (1978) Scherrer after sixty years: A. survey and some new results in the determination of crystallite size. J. Appl Cryst 11: 102-113.

[41] Inoue M, Hirasawa I. (2013) The relationship between crystal morphology and XRD peak intensity on $\mathrm{CaSO}_{4} \cdot 2 \mathrm{H}_{2} \mathrm{O}$. J. Crystal Growth 380: 169-175.

[42] Raza K, Kumar P, Ratan S, Malik R, Arora S. (2014) Polymorphism: The phenomenon affecting the performance of drugs. SOJ Pharm Pharm Sci 1: 10.

[43] Thiruvengadam E, Vellaisamy G. (2014) Polymorphism in pharmaceutical ingredients a review. World Journal of Pharmacy and Pharmaceutical Sciences 3: 621-633.

[44] Brittain HG (2009) Polymorphism in pharmaceutical solids in Drugs and Pharmaceutical Sciences, volume 192, $2^{\text {nd }}$ Edn, Informa Healthcare USA, Inc., New York.
[45] Blagden N, de Matas M, Gavan PT, York P. (2007) Crystal engineering of active pharmaceutical ingredients to improve solubility and dissolution rates. Adv Drug Deliv Rev 59: 617630 .

[46] Mosharrof M, Nyström C. (1995) The effect of particle size and shape on the surface specific dissolution rate of microsized practically insoluble drugs. Int J Pharm 122: 3547.

[47] Khadka P, Ro J, Kim H, Kim I, Kim JT, Kim H, Cho JM, Yun G, Lee J. (2014) Pharmaceutical particle technologies: An approach to improve drug solubility, dissolution and bioavailability. Asian J Pharm Sci 9: 304-316.

[48] Buckton G, Beezer AE. (1992) The relationship between particle size and solubility. Int J Pharmaceutics 82: R7-R10.

[49] Stuart BH. (2004) Infrared spectroscopy: Fundamentals and applications in Analytical Techniques in the Sciences. John Wiley \& Sons Ltd., Chichester, UK.

[50] Hesse M, Meier H, Zeeh B. (1997) Spectroscopic methods in organic chemistry, Georg Thieme Verlag Stuttgart, New York.

[51] Bajaj S, Singla D, Sakhuja N. (2012) Stability testing of pharmaceutical products. J. App Pharm Sci 2: 129-138. 